\title{
Beneficial effects of diatomite on the growth, the biochemical contents and polymorphic DNA in Lupinus albus plants grown under water stress
}

\author{
Mona M. Abdalla \\ Botany Department, Faculty of Science , Ain Shams University, Egypt \\ ABSTRACT
}

\begin{abstract}
Water is a major limiting factor in world agriculture and most crop plants are highly sensitive to even a mild water stress. The beneficial effects of diatomite is characterized by helping plants to overcome various biotic and abiotic stresses. Thus, this experiment was performed to study the ameliorative effect of diatomite $(10 \mathrm{~g} / \mathrm{kg})$ on each of growth, productivity, gas exchange , biochemical contents and polymorphic DNA of Lupinus albus L. plants grown in either well watered or two different soil water regimes ( 1 and 4 days withdrawal). Results showed that diatomite was able to alleviate the deteriorative effect of water stress on almost all measured criteria specially in plants grown under mild water stress $(1+D)$. Soil fertilization by diatomite significantly increased all measured growth parameters expressed as shoot and root length, fresh and dry weight of shoot, root and pods and number of pods/plant above both untreated and water stress -free diatomite treated plants. Diatomite application improved the rate of photosynthesis, stomatal conductance, the contents of each of total soluble sugars (TSS), total soluble protein (TSP) , total phenols, auxins, gibberellins, cytokinins and ABA and the activity of four antioxidant enzymes namely, superoxide dismutase (SOD), catalase (CAT), peroxidase (POD) and polyphenol oxidase (PPO) as compared to both control and stressed plants maintained at both levels of water regime. On the contrary, diatomite treatment markedly reduced transpiration rate and lipid peroxidation level to a minimum . Moreover, diatomite application either alone or combined with stress induced a distinctive protein electrophoratic band (92KD) which was absent in either the control or stressed plants. Three distinctive protein bands were also induced in stressed white lupin, two (65 and $25 \mathrm{KD}$ ) under one day drought and one (143K) under four day drought. Finally, diatomite induced several distinguished polymorphic DNA fragments using PCRRAPD analysis.
\end{abstract}

Keywords: diatomite, growth, gas exchange, total soluble protein , total soluble sugars, lipid peroxidation ,phenol, anti-oxidant enzymes, protein banding pattern and RAPD-DNA.

\section{INTRODUCTION}

Water is a fundamentally important component of the metabolism of all living organisms, facilitating many vital biological reactions by being a solvent, a transport medium, an evaporative coolant and providing the energy necessary to drive photosystem II reaction centre through water autolysis (Mundree et al,(2002).

Water stress usually causes a decrease in plant growth criteria and crop production. It causes changes of chlorophyll contents and components and damage of photosynthetic apparatus. It also inhibits the photochemical activities and decreases the activities of Calvin cycle enzymes. It breaksdown the balance between the production of reactive oxygen species (ROS) and the antioxidant defense system (as superoxide dismutase SOD; catalase CAT; peroxidase POD...etc.) causing the accumulation of ROS which induces oxidative stress to protein, membrane lipids and disruption of DNA strands. (Gong et al, 2005, El-Tayeb, 2006). Faraz Ahmed et al (2007) and Abdalla and El-Khoshiban (2007) reported that water stress increased the growth of roots but decreased those of shoots, number and area of leaves, fresh and dry weights of shoots and roots, the percentage of dry matter and the spike weight of wheat plants. Water stress also increases the levels of soluble sugars (compatible solutes) as glucose, sucrose, sorbitol, galactose, raffinose, stachyose and soluble proteins while it reduces the amounts of polysaccharides, starch and total sugars (Mundree et al, 2002; El Tayeb, 2006; Abdalla and El-Khoshiban, 2007). Several workers showed that water stress markedly reduced the amounts of auxins, gibberellins and cytokinin, while it reversibly raised the amounts of ABA (Nan et al, 2002; 
Kawakami et al, 2006; Zhang et al, 2006; Abdalla and El-Khoshiban, 2007).

Plants subjected to water stress showed a decrease in the large molecular weight fractions of proteins and an increase in the smaller molecular weight fraction (Moons et al, 1995) e.g. aquaporins (25-30 KD) (Arora et al, 2000).

Following cellular perception of water loss, a signaling mechanism was activated to induce specific genes. Expression patter ns of drought induced genes are complex. Some genes respond to stress rapidly as rd29A, Kin1, cor6.6 and cor47, whereas others are induced slowly after the accumulation of $A B A$ i.e. ABA-dependent signal transduction cascades between the initial signal of drought and the expression of specific genes as Em, rab, rd22, CDeT27-45 which are identified in stressed wheat, rice, Arabidopsis and Craterastigma plantagineum respectively (Bray, 1997; Hilbricht et al, 2002).

Diatomites de Mozambique (DDM) is a naturally occurring sedimentary rock primarily composed of fossilized remains of fresh water diatoms. It is chemically composed of $\mathrm{SiO}_{2}(86-89 \%)$ in a soluble form available to plants and small amount of trace elements. It is considered as a complete, long lasting, recyclable, reusable (donot breakdown or decompose like other growing mediums and thus economic) and environmentally friendly soil fertilizer and enhancer. It has a multifunctuional purpose: 1Improves the physical structure of soil by breaking up heavy based soil and retaining moisture in light or sandy soil for longer period (holds up to $200 \%$ of its weight in water) without interfering with soil chemistry . 2-Insulates, aerates, promotes capillary action and slowly release soluble silica to the plants as required due to its high absorbency and lateral water movement ability. 3- It minimizes leaching and run off thus reducing watering significantly. 4- It enables oxygen to penetrate the plant's root zone without any difficulty owing to its multifaceted shape. Thus, diatomite promotes stronger, healthier, higheryielding plants which mature quickly and acquire self resistance against abiotic and biotic stresses. Moreover, diatomite is used as an animal additive and natural physically killing insecticide (Kruger, 2006; Jessen, 2007; Abdalla, 2009).

Despite the prominence of $\mathrm{Si}$ within the plant's physical make up (0.2- $10 \%$ of plant dry weight depending on plant species; Epstein, 1999), Si has not yet been considered as an essential element and has not been included in any standard formulation of nutrient solutions and fertilizers, partly because its roles in plant biology are poorly understood (Liang et al, 2007). However, recently, numerous studies have demonstrated that silicon is one of the important elements of plants and plays an important role in tolerance of plants to environmental, heavy metal and biotic stresses ( Gong et al, 2005; Tahir et al, 2006).

With respect to water stress, relevant work is limited. Silicon is known to increase drought tolerance in plants by maintaining plant water balance, photosynthetic activity, erectness of leaves and structure of xylem vessels under high transpiration rates( Hattor i et al, 2005). Faraz Ahmed et al (2007)reported that increased levels of Si (50-150 $\mathrm{mg} / \mathrm{kg}$ soil) significantly increased plant biomass, plant height, spike weight and number and dry matter production under water stress (50\%) of field capacity. Nano structured $\mathrm{SiO}_{2}$ increased significantly the mean height, root diameter, main root length and number of lateral roots of larch seedlings by $42.5 \%$, $30.7 \%, 14.0 \%$ and $31.6 \%$ respectively (Baoshan et al, 2004). Both agronomists anh horticulturists reported that Si fertilization increases crop yield and quality and thus insures high production under severe biotic and abiotic stresses (Hou et al, 2007). Silicon application under drought stress $(-0.05 \mathrm{MPa})$ reduced stalk lodging, and increased mean tuber weight, thus potato yield is highly increased as compared to untreated stressed plants (Crusciol et al, 2009). Application of $\mathrm{Si}$ in the nutrient solution strongly influences water loss in plants by reducing cuticular transpiration while in the meantime it increases carbon dioxide assimilation rates, leaf stomatal conductance and enhances the strength of tissues, resulting in increased resistance of plants to water deficiency. (Gong et al, 2005; Hou et al, 2007). Rice plants grown with 100ppm $\mathrm{SiO}_{2}$ showed an extenstively higher level of cell wall polysaccharides (polygalactuoranic acid, pectin and lignin) in the leaf (Agarie et al, 1998). Moreover, Si raised the level of sucrose, raffinose and different water-soluble carbohydrates in treated grapes and banana (Kidane and Liang, 2008; Lynch, 2008). Si-treated plants showed increased amounts of total soluble proteins, phenols, antioxidant enzyme activities as SOD, POD and CAT ...etc and reduced lipid peroxidation level (Lima Filho et al, 2005: Tale Ahmad and Haddad, 2008; Crusciol et al, 2009); increased contents of auxins, gibberellins and abscisic acid (ABA) and, in contrast, decreased concentration of zeatin riboside 
under stress conditions (Dakora and Nelwamando, 1996; Jang et al, 2007).

Recently, group of workers isolated and characterized eight genes in rice (Lsi1, Lsi2, Lsi6), maize (ZmLsi1, ZmLsi2, ZmLsi6) and barley (HvLsi1, HvLsi2 ) that encodes for specific Si uptake and membrane transporter proteins. Each gene shared more than $80 \%$ identify between the 3 plant species. Lsi1 is mapped to chromosome 2 flanked by microstalleite marker RM5303, it belongs to the nodulin 26-like major intrinsic protein (NIP) family. The mRNA of Lsi1, Lsi2, ZmLsi1, ZmLsi2, HvLsi1 and HvLsi2 were mainly expressed in the roots. All Lsi1- like transporters are localized at the distal side of the plasma membrane of epidermis, hypoder mis and cortex and showed Si influx transport activity from the external solutions while Lsi2-like transporters are localized at the proximal side and showed efflux activity to the xylem of roots (Mitani et al, 2008). Lsi6-like transporters are $77 \%$ identicatal to Lsi at amino acid level. They are expressed in the root tip, leaf sheath and leaf blades and are localized at their xylem parenchyma tissues, they are responsible for $\mathrm{Si}$ transport out of the xylem throughout the leaf (Yamaji et al, 2008).

The present investigation was conducted to determine whether diatomite increases the drought tolerance of Lupinus albus plants and if such tolerance is correlated with changes in growth and gas exchange measurements, osmolytic compounds, antioxidant enzymes, photohormones, protein profiles and genomic DNA so as to investigate the mechanism of action of diatomite in enduring drought.

\section{MATERIALS AND METHODS}

Plant material and treatments: Seeds of Lupinus albus L. were obtained from the Agricultural Research Center, Giza, Egypt. They were surface sterilized with $1 \%$ sodium hypochlorite for $10 \mathrm{~min}$.,then washed thoroughly with distilled water and thereafter soaked for $4 \mathrm{hrs}$ in distilled water. Afterwards, the seeds were sown in 60 plastic pots $(20 \mathrm{~cm}$ in diameter and $19 \mathrm{~cm}$ in depth) containing $2.5 \mathrm{~kg}$ of garden soil per pot. The soil in 30 pots were evenly mixed with DDM diatomite at concentration $10 \mathrm{gm} / \mathrm{kg}$ soil in each pot. DDM diatomite is a natural diatomaceous earth originated from fossilized remains of fresh water diatoms with cell wall impregnated with silica. It is $\mathrm{pH}$ neutral and composed mainly of $\mathrm{SiO}_{2}(86-89 \%)$ in a soluble form beneficial to plants (table1)

\begin{tabular}{|l|l|}
\hline \multicolumn{2}{|l|}{ Major Chemical Elements } \\
\hline $\mathrm{SiO}_{2}$ & $89.00 \%$ \\
\hline $\mathrm{Al}_{2} \mathrm{O}_{3}$ & $5.95 \%$ \\
\hline $\mathrm{Fe}_{2} \mathrm{O}_{3}$ & $0.88 \%$ \\
\hline $\mathrm{CaO}$ & $0.10 \%$ \\
\hline $\mathrm{K}_{2} \mathrm{O}$ & $0.63 \%$ \\
\hline $\mathrm{MgO}$ & $0.20 \%$ \\
\hline $\mathrm{Na}_{2} \mathrm{O}$ & $0.32 \%$ \\
\hline $\mathrm{TiO}_{2}$ & $0.29 \%$ \\
\hline $\mathrm{H}_{2} \mathrm{O}$ & $<3 \%$ \\
\hline
\end{tabular}

Seven days after sowing, thinning was done so as to leave four seedlings/ pot. All pots were irrigated at the full field capacity (100\%) for three weeks in order to improve root development before initiating water stress treatments. The pots were arranged into 6 sets, 10 pots/set as follows.

*The first two sets either containing or not containing diatomite were irrigated daily ( 0 and $0+D)$.

* The second two sets either containing or not containing diatomite were irrigated after one day drought (1 and $1+D)$.

* The third two sets either containing or not containing diatomites were irrigated after four days from water withdrawal (4 and 4+D).

The experiment was conducted in green house conditions at average day/night temperature $30^{\circ} / 20^{\circ} \mathrm{C}$ \pm 2 , relative humidity $60-65 \% \pm 2$ and ambient light. The plants were harvested at 120 days after sowing (DAS) at pod- filling stage. Ten plants were randomly selected for the measurement of growth criteria and gas exchange, another samples were taken (5 replicates/ treatment) and either oven dried for determination of polysaccharides, total soluble sugars and proteins or frozen in liquid nitrogen for enzymes, phenol, lipid peroxidation, total protein electrophorasis and RAPD analysis of genomic DNA.

Measurement of gas exchange: Photosynthesis and transpiration rates and stomatal conductance were measured using an open gas portable photosynthesis system (LI- 6400, LI-COR, Bio Sciences, USA). Measurements were performed on sunny days under natural light conditions and between 9-12 am on the uppermost fully expanded leaves of 10 plants randomly chosen per treatment 
and expressed on a leaf area basis (Renault et al, 2001).

2.3. Biochemical and hormonal analysis: Carbohydrate fractions were extracted, clarified and determined as total soluble sugars (Dubois et al, 1965). Polysaccharides were extracted from leaves as described by Motomura (1990) and the total sugars in the solution after incubation with the amyloglucasidase (600 unit $\mathrm{mL}^{-1}$ ) was determined as described by Nelson (1944). To estimate soluble proteins, powdered leaf samples were extracted with boiled distilled water and the soluble proteins were determined according to Lowry et al (1951). Total phenols were determined in the ethanolic extract following the method described by Simons and Ross (1971) using folin reagent.The level of lipid peroxidation in leaf tissues was measured by the determination of $n$ mole of malonodialdehyde (MDA) formed using an extinction coefficient of $155 \mathrm{mmol}$ $\mathrm{L}^{-1} \mathrm{~cm}^{-1}$. MDA was determined using $20 \%$ trichloroacetic acid containing $0.5 \%$ thiobarbituric acid (TBA) reaction and the developed colour was extracted with $2 \mathrm{ml}$ n-butanol and the absorbance was measured at $532 \mathrm{~nm}$. The value for the non- specific absorbtion at 600nm was subtracted (Zhao et al, 1994).

For the assay of antioxidant enzymes (catalase, CAT; peroxidase, POD , polyphenol oxidase, PPO and superoxide dismutase, SOD), fresh material were extracted following the method of Guerrier and Strullu (1990). The activities of CAT and POD were determined according to Chance and Maehly (1955). CAT activity was determined by measuring the decomposition of $\mathrm{H}_{2} \mathrm{O}_{2}$, by following the decline in its absorbance at $240 \mathrm{~nm}$ for $3 \mathrm{~min}$. POD activity was assayed by measuring the oxidation of guaiacol and the increase in absorbance at $470 \mathrm{~nm}$ was recorded for 3min, while that of PPO was according to the procedure adopted by Kar and Mishra (1976). The activity was defined as $0 \mathrm{D} / \mathrm{min} / \mathrm{mg} \mathrm{FW}$. SOD activity was assayed by the nitrobluetetra zolium (NBT) modification method from that described by Dhindsa et al (1980). One unit of SOD was defined as that being contained in the volume of extract that caused a $50 \%$ inhibition of the SOD- inhibitable fraction of the NBT reduction. For estimation of growth regulators , fresh samples of leaves were extracted in ethanol according to Wasfy et al (1974), then fractionated into acidic fraction containing the acidic hormones IAA, $\mathrm{GA}_{3}$ and $\mathrm{ABA}$ while the aqueous fraction comprised the cytokinins. Both fractions were estimated using high performance liquid chromatography (HPLC) according to the method described by Shindy and Smith (1975).

Morphologic and gas exchange values are means \pm standard error of 10 replicates while those of biochemical and hormonal values are means \pm standard error of 5 replicates. Significant differences were calculated using student's (t) test. SPSS was peformed for multiple comparisons .

Electrophoratic analysis of total proteins was performed according to Laemmli (1970) using sodium dodecyl sulphate polyacrylamide gel electrophorasis (SDS-PAGE). Staining of gel with silver nitrate was according the method of Goldberg and Warner (1997) and then scanning them using Gel doc 2000 system followed by analysation with software supplied by the manufacturer.

Genomic DNA of white lupine leaves were extracted according to Graham and Henry (1997) and random amplified polymorphic DNA (RAPD) analysis was performed according to Williams et al (1990) using 3 of 10-mer random primers obtained from Metabion AG Lena Christ Strasse, Martinstried, Deutschland as shown in table(2)

Table (2):The random primer names and sequences used in RAPD analysis

\begin{tabular}{ll}
\hline RAPD primer name & Sequence (5' '3) \\
\hline B05 & TGCGCCCTTC \\
B08 & GTCCACACGG \\
B011 & GTAGACCCGT \\
\hline
\end{tabular}

Amplification reactions were performed in a final volume of $25 \mu \mathrm{l}$ containing : $2.5 \mu \mathrm{l} 10 \times \mathrm{PCR}$ buffer, $1.25 \mu \mathrm{l} 50 \mathrm{mM} \mathrm{MgCl}, 2.5 \mu \mathrm{l} 2 \mathrm{mM}$ dNTP, $0.625 \mu \mathrm{l}$ $10 \mathrm{mM}$ primer, $2.3 \mu$ ng DNA, $1 \mu \mathrm{l} 5 \mu \mathrm{g}$ Tag polymerase and $16 \mu \mathrm{l}$ Millipore $\mathrm{H}_{2} \mathrm{O}$. Reactions were performed using a Thermal cycler (Biometra, biomedizinische Analytic $\mathrm{GmbH}$ ). The PCR was performed with the cycle program of denaturation (one cycle) $94^{\circ} \mathrm{C}$ for $2.5 \mathrm{~min}$, annealing 40 cycles of $1 \mathrm{~min}$. at $94^{\circ} \mathrm{C}, 1 \mathrm{~min}$. at $37^{\circ} \mathrm{C}, 1 \mathrm{~min}$. at $72^{\circ} \mathrm{C}$ and with a final extention of $10 \mathrm{~min}$. at $72^{\circ} \mathrm{C}$. PCR products were developed using ethidium bromide and visualized in UV using transilluminator.

\section{RESULTS AND DISCUSSION}


Growth responses: Results presented in table (3) demonstrated that diatomite treated white lupin displayed the highest growth rate expressed as shoot and root length, fresh and dry weight of shoots and roots and yield components (number of pods, fresh and dry weight of one pod/plant). Reversibly, water withdrawal for 1 and 4 days decreased all above growth increments as compared to well watered controls. The magnitude of decrease was much Table (3):Changes in growth parameters in response to diatomite treatment of Lupinus albus plants subjected to water stress. pronounced by increasing the severity of drought. Addition of diatomite to mild stressed plants, significantly elevated all growth measurements above those of untreated and stressed plants (1\&4) . However ,application of diatomite to severely stressed plants, raised all growth increments above untreated stressed plants (4), but slightly lower than control plants.

\begin{tabular}{|l|l|l|l|l|l|l|}
\hline \multirow{2}{*}{$\begin{array}{l}\text { Growth } \\
\text { measurements }\end{array}$} & $\mathbf{0}$ & $\mathbf{0 + D}$ & $\mathbf{1}$ & $\mathbf{1 + D}$ & $\mathbf{4}$ & 4+D \\
\cline { 2 - 7 } \\
\hline $\begin{array}{l}\text { Shoot } \\
\text { Length }\end{array}$ & $46.7 \pm 0.38$ & $62.9 \pm 0.41$ & $37.7 \pm 0.23$ & $49.6 \pm 0.63$ & $29.4 \pm 0.84$ & $43.2 \pm 0.91$ \\
\hline $\begin{array}{l}\text { Root } \\
\text { Length }\end{array}$ & $15.8 \pm 0.21$ & $18.2 \pm 0.34$ & $14.1 \pm 0.36$ & $17.0 \pm 0.68$ & $12.6 \pm 0.82$ & $14.3 \pm 0.56$ \\
\hline $\begin{array}{l}\text { Fresh weight of } \\
\text { shoot }\end{array}$ & $17.63 \pm 0.33$ & $26.32 \pm 0.46$ & $15.52 \pm 0.29$ & $20.02 \pm 0.48$ & $10.09 \pm 0.69$ & $15.37 \pm 0.35$ \\
\hline $\begin{array}{l}\text { Fresh weight of } \\
\text { root weight of }\end{array}$ & $13.12 \pm 0.67$ & $18.33 \pm 0.48$ & $14.91 \pm 0.25$ & $16.28 \pm 0.21$ & $17.34 \pm 0.19$ & $18.91 \pm 0.66$ \\
\hline $\begin{array}{l}\text { Dry why } \\
\text { shoot }\end{array}$ & $6.41 \pm 0.08$ & $3.49 \pm 0.07$ & $5.97 \pm 0.08$ & $2.15 \pm 0.09$ & $2.89 \pm 0.06$ \\
\hline Dry weight of root & $1.14 \pm 0.08$ & $1.76 \pm 0.05$ & $0.98 \pm 0.07$ & $1.43 \pm 0.02$ & $0.73 \pm 0.03$ & $1.01 \pm 0.02$ \\
\hline $\begin{array}{l}\text { Mean number of } \\
\text { pods/plant }\end{array}$ & $5.6 \pm 0.02$ & $7.9 \pm 0.04$ & $4.8 \pm 0.07$ & $6.8 \pm 0.05$ & $2.3 \pm 0.06$ & $3.9 \pm 0.05$ \\
\hline $\begin{array}{l}\text { Mean fresh weight } \\
\text { of one pod }\end{array}$ & $0.28 \pm 0.06$ & $0.37 \pm 0.07$ & $0.19 \pm 0.06$ & $0.32 \pm 0.06$ & $0.10 \pm 0.05$ & $0.18 \pm 0.03$ \\
\hline $\begin{array}{l}\text { Mean dry weight } \\
\text { of one pod }\end{array}$ & $0.16 \pm 0.04$ & $0.22 \pm 0.02$ & $0.085 \pm 0.01$ & $0.19 \pm 0.04$ & $0.038 \pm 0.02$ & $0.07 \pm 0.03$ \\
\hline
\end{tabular}

*The main difference is significant at 0.05 level

It is well known that Lupins termis is a drought sensitive plant (conservation plant characteristics, USDA), thus water stress significantly suppressed its growth measurements. Comparable results were obtained by kaya et al (2006), Abdalla and ElKhoshaiban (2007) using maize and wheat plants respectively. Such decline in shoot and root length in response to drought might be due to either decrease in cell elongation resulting from the inhibiting effect of water shortage on growth promoting hormones which, in turn, led to a decrease in each of cell turgor, cell volume and eventually cell growth (Banon et al, 2006), and/ or due to blocking up of xylem and phloem vessels thus hindering any translocation through (Lavisalo and Schuber, 1998). Moreover, the decline in both fresh and dry weight of shoots, roots and pods of white lupin reveals the influence of water in stimulating and regulating the photosynthetic enzymes and growth promoting hormones, which thus influence dry matter production (Monti et al, 2006). Conversely, Si promoted the height, strength, 
total soluble sugars (TSS) and total soluble protein (TSP) by $34.7 \%, 32.6 \%, 21 \%, 28.6 \%$ and $6 \%$ while it depressed the transpiration rate by $39.2 \%$ above and below those of untreated controls respectively (table 4). Plants subjected to both levels of water withdrawal manifested declining levels in each of photosynthesis, transpiration, stomatal conductance and polysaccharides while in the meantime the Table (4): Changes in gas exchange measurements, polysaccharides, total sugars and total soluble proteins in response to diatomite treatment of Lupinus albus plants subjected to water stress.

\begin{tabular}{|l|l|l|l|l|l|l|}
\hline Treatments & $\begin{array}{l}\text { Photosynthetic } \\
\text { rate( }\left(\boldsymbol{\mu m o l e} \quad \mathbf{C O}_{\mathbf{2}}\right. \\
\mathbf{m}^{-2} \mathbf{s}^{-\mathbf{1}} \text { ) }\end{array}$ & $\begin{array}{l}\text { Transpiration } \\
\text { rate(mole } \mathbf{H}_{\mathbf{2}} \mathbf{O} \\
\mathbf{m}^{-2} \mathbf{s}^{-2} \text { ) }\end{array}$ & $\begin{array}{l}\text { Stomatal } \\
\text { Conductance } \\
\mathbf{c m ~ s}^{-1} \text { ) }\end{array}$ & Polysaccharides & $\begin{array}{l}\text { Total } \\
\text { soluble } \\
\text { sugars }\end{array}$ & $\begin{array}{l}\text { Total } \\
\text { soluble } \\
\text { proteins }\end{array}$ \\
\hline $\mathbf{0}$ & $14.7 \pm 0.08$ & $3.52 \pm 0.02$ & $0.196 \pm 0.01$ & $64.7 \pm 0.06$ & $21.3 \pm 0.63$ & $118.9 \pm 0.1$ \\
\hline $\mathbf{0 + D}$ & $19.8 \pm 0.09$ & $2.14 \pm 0.04$ & $0.26 \pm 0.03$ & $78.2 \pm 0.14$ & $27.4 \pm 0.78$ & $126.7 \pm 0.7$ \\
\hline $\mathbf{1}$ & $12.6 \pm 0.11$ & $3.12 \pm 0.06$ & $0.12 \pm 0.01$ & $48.4 \pm 0.23$ & $29.8 \pm 0.66$ & $139.1 \pm 0.66$ \\
\hline $\mathbf{1 + D}$ & $16.9 \pm 0.09$ & $2.96 \pm 0.04$ & $0.20 \pm 0.02$ & $70.3 \pm 0.36$ & $34.6 \pm 0.82$ & $148.4 \pm 0.51$ \\
\hline $\mathbf{4}$ & $8.7 \pm 0.07$ & $2.83 \pm 0.03$ & $0.069 \pm 0.04$ & $29.2 \pm 0.34$ & $38.5 \pm 0.76$ & $151.8 \pm 0.39$ \\
\hline 4+D & $13.8 \pm 0.06$ & $2.36 \pm 0.01$ & $0.10 \pm 0.08$ & $56.1 \pm 0.44$ & $45.7 \pm 0.63$ & $169.2 \pm 0.65$ \\
\hline
\end{tabular}

*The mean difference is significant at 0.05 level

N.B.: Values of polysaccharides, total soluble sugars (TSS) and total soluble proteins were expressed as mg/g . DW.
Similar results were recorded in variously Si-treated plants (Kosobryukhov et al, 2008; Lalljee, 2008; Abdalla, 2009). The ameliorative effect of diatomite on water stressed plants depends on the ability of $\mathrm{Si}$ to deposit as colloidal silica gel $\left(\mathrm{SiO}_{2}\right)$ in the xylem vessels and the cell walls of leaves which thus restrict the bypass flow of transpired water that crosses the root cells towards the xylem vessels and present a barrier to cuticular transpiration (Carvalhopupatto et al, 2005, Savvas et al, 2009). These effects of $\mathrm{Si}$ increase the relative water content of plant tissues thus keeping the leaves erect and strengthen the stem which, in turn, prevent lodging and improves light penetration into plant community thus improving photosynthesis(Faraz Ahmad et al, 2007; Abdalla, 2009). The enhanced photosynthetic rates in response to $\mathrm{Si}$, promotes the supply of cell wall material e.g. cell wall polysaccharides as lignin polymers and pectic network of the primary wall (Agarie et al, 1998; Balec et al, 2005) and the supply of soluble carbohydrates as, sucrose, raffinose ...etc. (Kidane and Liang, 2008; Abdalla, 2009),which stimulates root growth and activity that enhances water and nutrient uptake (Faraz Ahmad et al, 2007). Soluble sugars, soluble proteins and free amino acids including proline accumulated significantly in response to drought stress (El-Tayeb, 2006).The accumulation of these compounds protect the cell values of each of TSS and TSP were significantly raised above those of daily irrigated plants. Fertilization of stressed plants with diatomite (1+D) \& $(4+D)$ obviously elevated all mentioned values with the exception of transpiration rate which declined significantly as compared to untreated stressed plants. under stress by balancing the osmotic strength of the cytosol with that of the vacuole and the external environment. They also interact with cellular macromolecules as enzymes and stabilize their structure (El-Tayeb, 2006). Subjecting water stressed Lupinus albus plants to diatomite synergistically increased the amounts of soluble sugars and proteins than in untreated stressed ones which indicated that accumulation of these compounds by diatomite plays a key role in retaining the water capacity of stressed cells which thereby can tolerate severe drought (Tale Ahmad and Haddad, 2008; Gong et al, 2008; Crusciol et al, 2009).

Total phenol, lipid peroxidation and antioxidant enzyme activity: It is apparent from table (5) that the levels of both total phenol and lipid peroxidation and the measured activity of the four antioxidant enzymes (SOD, POD, CAT and PPO) were markedly stimulated as a response to water stress. These findings were concurrent with those of El-Tayeb (2006) and Abdalla and El-Khoshaiban (2007). Application of diatomite either unique or to stressed white lupin plants progressively elevated all these parameters even more that in untreated or diatomite - free stressed plants with the exception that the level of lipid peroxidation obviously declined due to diatomite fertilization. 
Table 5: Changes in the total phenol and lipid peroxidation levels and the activities of SOD, CAT, POD and PPO in response to diatomite treatment of Lupinus albus plants subjected to water stress.

\begin{tabular}{|l|l|l|l|l|l|l|}
\hline Treatments & $\begin{array}{l}\text { Lipid } \\
\text { peroxidation } \\
\text { level }\end{array}$ & Total phenol & $\begin{array}{l}\text { Superoxide } \\
\text { dismutase }\end{array}$ & Catalase & Peroxidase & $\begin{array}{l}\text { Polyphenol } \\
\text { oxidase }\end{array}$ \\
\hline $\mathbf{0}$ & $0.92 \pm 0.04$ & $17.6 \pm 0.31$ & $2.3 \pm 0.08$ & $567 \pm 0.09$ & $612 \pm 0.92$ & $56 \pm 0.63$ \\
\hline $\mathbf{0 + D}$ & $0.81 \pm 0.03$ & $19.8 \pm 0.28$ & $2.9 \pm 0.07$ & $572 \pm 0.91$ & $673 \pm 0.86$ & $64 \pm 0.54$ \\
\hline $\mathbf{1}$ & $5.64 \pm 0.09$ & $22.8 \pm 0.36$ & $3.2 \pm 0.06$ & $642 \pm 0.87$ & $741 \pm 0.73$ & $73 \pm 0.82$ \\
\hline $\mathbf{1 + D}$ & $0.99 \pm 0.05$ & $27.1 \pm 0.28$ & $3.8 \pm 0.09$ & $681 \pm 0.93$ & $791 \pm 0.97$ & $86 \pm 0.79$ \\
\hline $\mathbf{4}$ & $7.35 \pm 0.13$ & $28.6 \pm 0.39$ & $3.9 \pm 0.04$ & $768 \pm 0.96$ & $814 \pm 0.98$ & $85 \pm 0.63$ \\
\hline 4+D & $1.35 \pm 0.02$ & $36.9 \pm 0.24$ & $4.6 \pm 0.03$ & $814 \pm 0.85$ & $853 \pm 0.84$ & $92 \pm 0.92$ \\
\hline
\end{tabular}

N.B.: Values of lipid peroxidation were expressed as nmol MDA/g.FW, total phenol as $\mathrm{mg} / \mathrm{g} . \mathrm{FW}$, SOD as units/mg protein/ min and those of CAT, POD and PPO as $\mathrm{mg} / \mathrm{g} . \mathrm{FW} . / \mathrm{hr}$.

Similar results were obtained by several workers using wheat plants (Lima Filha et al, 2005; TaleAhmad and Haddad, 2008, Gong et al, 2008). It is postulated that diatomite application increased markedly the resistance of plants to different forms of environmental stresses by increasing the activity of antioxidant enzymes and phenols so as to scavange the increased level of reactive oxygen species (ROS) that prevail under stress thus causing $\mathrm{H}_{2} \mathrm{O}_{2}$ production and lipid peroxidation to be at minimum levels while membrane stability and cellular osmoregulation at maximum (Tale Ahmad and Haddad, 2008). Further more, several studies on monocot and dicot plants supplied with $\mathrm{Si}$ have shown that under stress, silicon activities some plant defense mechanisms as phenolics and phytoalexins and antioxidant enzymes as PPO, POD and chitinase (Ma and Yamaji, 2006).

Hormonal content: The hormonal contents of Lupinus albus leaves of differently treated and untreated plants were shown in figure (1). Application of both levels of water regime gradually declined the contents of all growth ptomoting hormones (auxins, gibberellins and cytokinins) while reversibly raised the abscisic acid (ABA) amount below and above those of the untreated controls respectively. These results were similar to those of Zhang et al (2006) and Abdalla and El-Khoshiban (2007) who found that water stress decreased the content of each of $\mathrm{GA}_{3}$, $G_{4}, I A A$ and zeatin whereas it increased $A B A$ values. On the other side, fertilization of unstressed and stressed white lupin with diatomite clearly elevated all levels of plant hormones as compared to untreated control and stressed plants. Noteworthy that the ameliorative effect of diatomite were more pronounced with the increase in the severity of drought. Comparable works reveal that Si application correct the negative effect of stress on endogenous plant hormones by increasing growth promoters (auxins, gibberellins and cytokinins) and increasing growth retardants (ABA). (Hanafy Ahmed et al, 2008) , although another work showed that ABA was increased while zeatin was decreased in silicon treated cowpea plants (Dakora and Nelwamondo, 1996). The stimulation of morphological characteristics and physiological activities (photosynthesis, transpiration, antioxidant enzymes coupled with the accumulation of osmolytes and phenols) were closely related with the optimization of hormonal balance in water stressed white lupin following diatomite treatment. In addition, diatomite enhancement of ABA accumulation in stressed leaves induces the closure of stomata thus resulting in a high leaf water potential under stress conditions (Zhang et al, 2006).

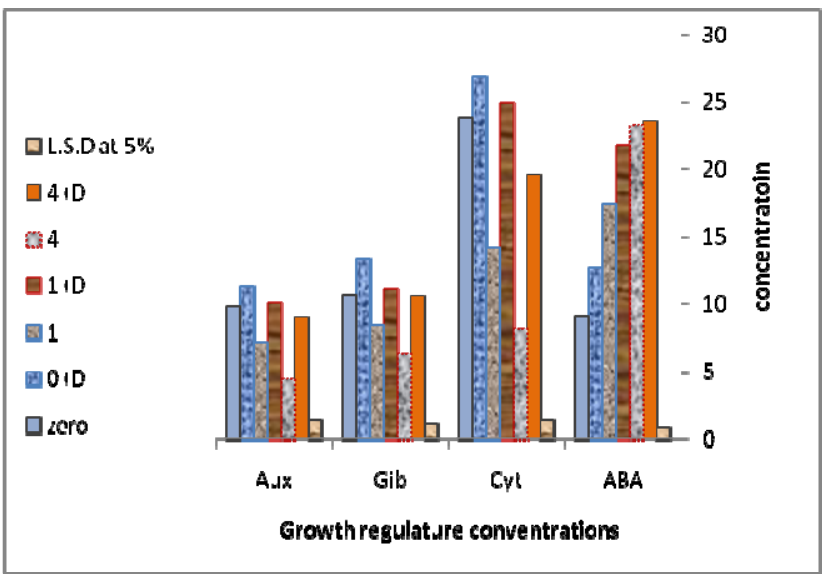

Fig 1: Changes in growth hormones(mg/kg.F.wt.) in response to diatomite treatment of Lupinus albus plants subjected to water stress. 
Table 6: SDS- PAGE analysis of protein bands of leaves of diatomite treated Lupinus albus plants subjected to water stress.

\begin{tabular}{|c|c|c|c|c|c|c|c|}
\hline \multirow{2}{*}{$\begin{array}{l}\text { Band } \\
\text { number }\end{array}$} & \multirow{2}{*}{$\begin{array}{l}\text { M.W. } \\
\text { (K.D.) }\end{array}$} & \multicolumn{6}{|c|}{ Band\% } \\
\hline & & 0 & $0+D$ & 1 & $1+\mathrm{D}$ & 4 & $4+D$ \\
\hline 1 & 230 & 2.9 & 4.8 & 5.2 & 6.7 & 5.9 & 7.3 \\
\hline 2 & 190 & & 2.7 & 3.5 & 4.7 & 6.3 & 8.9 \\
\hline 3 & 178 & $\overline{3} .6$ & 4.8 & 5.9 & 6.7 & 7.4 & 9.8 \\
\hline 4 & 174 & 3.3 & 4.2 & 5.0 & 6.2 & 6.8 & 8.7 \\
\hline 5 & 161 & 4.6 & 5.8 & 6.4 & 7.7 & 8.9 & 10.1 \\
\hline 6 & 152 & - & 2.7 & 3.8 & 4.5 & 5.4 & 6.3 \\
\hline 7 & 143 & & & & 5.8 & 6.4 & 8.8 \\
\hline 8 & 130 & $\overline{5} .4$ & $\overline{6} .8$ & $\overline{7} .3$ & 8.2 & 9.6 & 11.2 \\
\hline 9 & 120 & 3.2 & 4.6 & 5.7 & 6.8 & 7.6 & 8.2 \\
\hline 10 & 112 & 6.8 & 7.5 & 8.4 & 8.8 & 9.6 & 10.3 \\
\hline 11 & 102 & - & 3.4 & 4.8 & 5.6 & 4.6 & 5.4 \\
\hline 12 & 92 & & 4.2 & & 7.8 & & 5.9 \\
\hline 13 & 80 & $\overline{2} .3$ & 3.6 & $\overline{4} .1$ & 5.6 & $\overline{6} .4$ & 7.8 \\
\hline 14 & 65 & & & 5.2 & 6.4 & 7.8 & 9.2 \\
\hline 15 & 53 & $\overline{4} .6$ & $\overline{5} .1$ & 6.4 & 8.9 & 7.3 & 8.5 \\
\hline 16 & 47 & - & 7.2 & 8.0 & 9.2 & 9.6 & 11.8 \\
\hline 17 & 34 & - & 3.8 & 4.3 & 5.6 & 6.6 & 7.9 \\
\hline 18 & 25 & & & 5.8 & 8.7 & 7.9 & 8.5 \\
\hline 19 & 12 & $\overline{2} .6$ & $\overline{3} .6$ & 4.7 & 5.8 & 6.9 & 7.6 \\
\hline \multicolumn{2}{|c|}{$\begin{array}{l}\text { Total no. of } \\
\text { bands }\end{array}$} & 10 & 16 & 17 & 19 & 18 & 19 \\
\hline \multicolumn{2}{|c|}{$\begin{array}{l}\text { No. of new } \\
\text { bands }\end{array}$} & - & 6 & 7 & 9 & 8 & 9 \\
\hline \multicolumn{2}{|c|}{$\begin{array}{l}\text { No. of } \\
\text { disappeared } \\
\text { bands }\end{array}$} & 9 & 3 & 2 & - & 1 & - \\
\hline
\end{tabular}

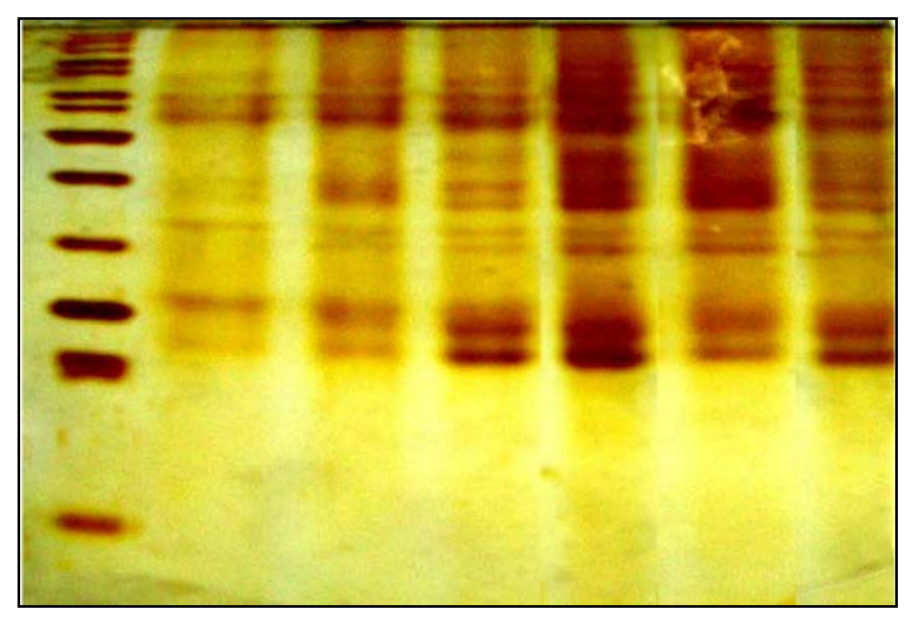

\begin{tabular}{|l|l|l|l|l|l|l|l|}
\hline M & 1 & 2 & 3 & 4 & 5 & 6 & M \\
\hline
\end{tabular}

Fig 2. SDS-PAGE profile of total proteins extracted from leaves of lupine plants undergo drought for 1 and 4 days and treated with diatoms. $M=$ molecular marker (kD)
Biochemical genetic markers(SDS-protein electrophorasis): SDS-electrophoatic patterns of leaf total protein of diatomite treated and untreated plants grown under 2 water regimes were represented in table (6) and figure (2). The total number of bands were 19 having molecular weights ranged from 230 to $12 \mathrm{KD}$. Among such bands, 11 ones were commonly detected while the other bands showed obvious variability in response to various treatments $(0+D, 1,1+D, 4,4+D)$. Six induced protein bands having molecular weights 190, 152, 102, 92, 47 and $34 \mathrm{KD}$ were observed in diatomite treated plants and were absent in the control. Under 1 day of drought stress, two distinguish protein bands were induced with 65 and $25 \mathrm{KD}$ which were absent in both the control and diatomite treated plants, while under severe drought (4), one more band with 143 $\mathrm{KD}$ was detected as comparable to one day stress(1). On the other hand, addition of diatomite to plants imposed to both grades of stress $(1+D, 4+D)$, not only recovered but even encouraged white lupin plants to operate new silence genes so as to express new protein as a natural defense response to stress. This distinctive new protein band had molecular weight $92 \mathrm{KD}$. Noteworthy that this band was only present in diatomite treated unstressed and stressed plants . Compatible with these results, Arora et al (2000) professed that water stress induces the accumulation of stress responsive proteins belonging to dehydrin group (25-60KD) and/or aquaporins (2530KD)

Figure( 2): SDS- PAGE analysis of protein bands of leaves of diatomite treated Lupinus albus plants subjected to water stress.

The former are groups of membrane bound proteins that regulate the permeability of membrane to water and influence water movement among tissues and cells thus maintaining their normal turgidity, whereas the latter ones act as stabilizers (chaperon-like) that prevent or reduce the denturation of other cellular micromolecules under dehydration (Campbell et al, 1998). Moreover, Garwe et al (2002) have suggested that a stress responsive protein (XVSAP1) was expressed in the dehydrated leaves of a xerophytic plant Xerophyto viscose.It was involved in the repair of membrane damage resulting from water deficit.

With respect to diatomite; recent researches have manifested that Si promotes the expression of plant stress genes (signaling cascades) as a natural defense response that translate and activate a strategic signaling protein known as proline-rich 
protein (PR protein) and a mitogen activated protein kinase (MAP-kinase). These proteins transmit information to the nucleus by the phosphorylation of hydroxyl groups on amino acid residues. Si is known to bind to hydroxyl groups, thus affecting protein activity and conformation. Such newly- synthesized proteins help the plant to act as a potentiator for defense responses against abiotic and biotic responses (Fauteux et al, 2006).

Molecular genetic markers:- (PCR-RAPD analysis): Three arbitrary random amplified polymorphic DNA(RAPD) primers, B05, B08 and B011 were used to amplify the genotypes of untreated and diatomite treated Lupinus albus plants subjected to two grades of water regime (figure 3 , table7).

A total of 40 amplified DNA fragments ranging in size from 5433 to $148 \mathrm{bp}$ were realized using the 3 pimers , among which 23 fragments were polymorphic while 17 were commonly detected in treated and untreated samples. The polymorphic percentage of the 3 primers were 72, 62 and $63 \%$ successively . RAPD analysis of white lupin revealed the induction of 17 distincive bands due to diatomite treatment of stressed and unstressed plants using the 3 primers. For instance, one unique fragment with 1382 bp due to diatomite treatment of unstressed plants using primer B05; three fragments with 3508, 2827 (using primer B05) and 5164 bp (using primer B08) in response to diatomite treatment of unstressed and one day stressed plants $(0+D, 1+D)$; another five fragments with 788, 265 (using primer B05), 421, 148 (using primer B05) and 225 bp (using primer Bo11) due to diatomite treatment of unstressed and both grades of stressed plants $(0+D, 1+D$ \&4+D); moreover four fragments with 5433, 3977, 278 (using primer B011) and $210 \mathrm{bp}$ (using primer B08) in response to $0,0+D, 1+D$ and $4+D$ treatments; three more amplified fragments with 148, 36 and $1859 \mathrm{pb}$ using primers B05, B08 and B011 respectively as a consequence of diatomite treatment of 1 and 4 day stressed plants; and finally a distinctive fragment with 452 bp using primer B05 was induced in response to all treatments except the control. Reversibly, another 6 amplified DNA fragments were induced as a consequence of stress, the first 3 fragments with 696, 2427 and 186 pb using primers B05; B08 and B011 successively were determined in control and both grades of stress $(0,1$ and 4$)$ while the other 3 fragments with 3900, 279 (using primer B08) and 676 pb (using primer B011) were induced under stress only (1 and 4). Noteworthy that diatomite application to both unstressed or variously stressed plants induced the highest number of DNA amplified segments as compared to either control or stressed plants. These criteria can be considered as a positive genetic marker for diatomite tolerance to stress condition. These results were accommodated with similar studies. Bakhat et al (2009) showed that only 2 genes were affected when Si was supplied under normal condition, while the expression of nearly 4000 genes were altered due to Si treatment under stress condition (Fauteux et al, 2006). It is suggested that the increased expression of a large number of genes as a consequence of diatomite application might be due to the involvement of $\mathrm{Si}$ in the defense mechanism of plants against the deteriorative effect of drought which can be achieved by the co-expression of certain protective genes as XVPer1 which protect DNA molecule from the reactive oxygen species produced under drought, together with XVSAP1 which prevents membrane leakage, and XVGols and ALDRXV4 are osmo protectance that confer drought tolerance, and/or the expression of another type of genes specified for the increased uptake and accumulation of $\mathrm{Si}$ in plants as Lsi1, Lsi2 and Lsi6 which were detected in graminceous plants. These genes stimulate the uptake and accumulation of $\mathrm{Si}$ in the leaves of graminaceous plants by expressing specific active membrane transporters. Accumulation of $\mathrm{Si}$ as insoluble $\mathrm{SiO}_{2}$ beneath the cuticle confers physical resistance against biotic and abiotic stresses (Mundree et al, 2002; Mitani et al 2008; Yamaji et al, 2008). A recent study showed that during the induction of systemic acquired resistance (SAR) in cucumber, the expression of a gene incoding a novel proline rich protein was enhanced. This protein has C-terminal repeatitive sequences containing an unusual high amount of lysine and arginine. The synthetic peptide derived from the repeatitive sequences polymerize orthosilithic acid to insoluble silica, thus reinforcing cell wall against stresses (Ma and Yamaji, 2006). 

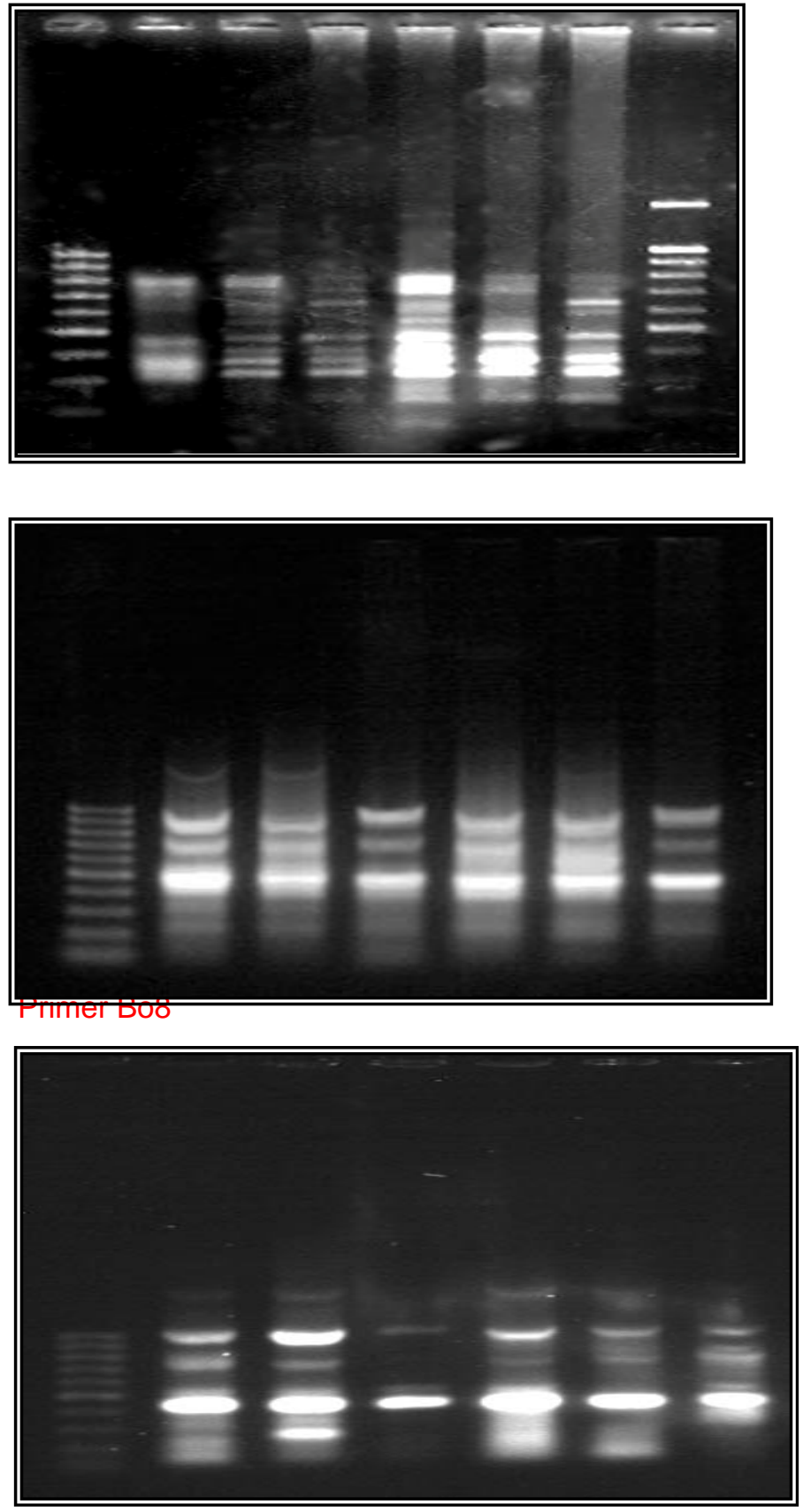

Fig 3 : RAPD amplified bands of Lupinus albus leaves using three random primers.
Thus, the key mechanism of diatomite mediated alleviation of water deficit stress in white lupin include:-

Enhancement of plant growth via increased cell extensibility and elongation mediated by growth promoting phytohormones and via improved photosynthesis and root activity.

Alleviation of osmosis stress via reduction of transpiration mediated by $\mathrm{ABA}$ and/or better water retention.

Stimulation of antioxidant defense activity and osmoprotectants while reduction of lipid peroxidation.

Improvement of plasma membrane and tonoplast structure, intergrity and functions.

Future prospects: Plants growing in the field are constantly subjected to an array of stresses that $\mathrm{Si}$ may alleviate. Accordingly, graminaceous plants that accumulate large quantities of $\mathrm{Si}$ benefit the most. Unlike monocot, most dicots cannot accumulate Si in large enough amount to be beneficial, genetically manipulating the Si uptake capacity of the root might help these plants to accumulate more Si and, hence, more able to overcome both biotic and abiotic stresses. Thus, furtherwork is needed so as to isolate and characterize more specific genes which are either responsible for $\mathrm{Si}$ uptake in dicots or associated with stress tolerance by Si. 
Table(7) : RAPD amplified bands of Lupinus albus leaves using three random primers.

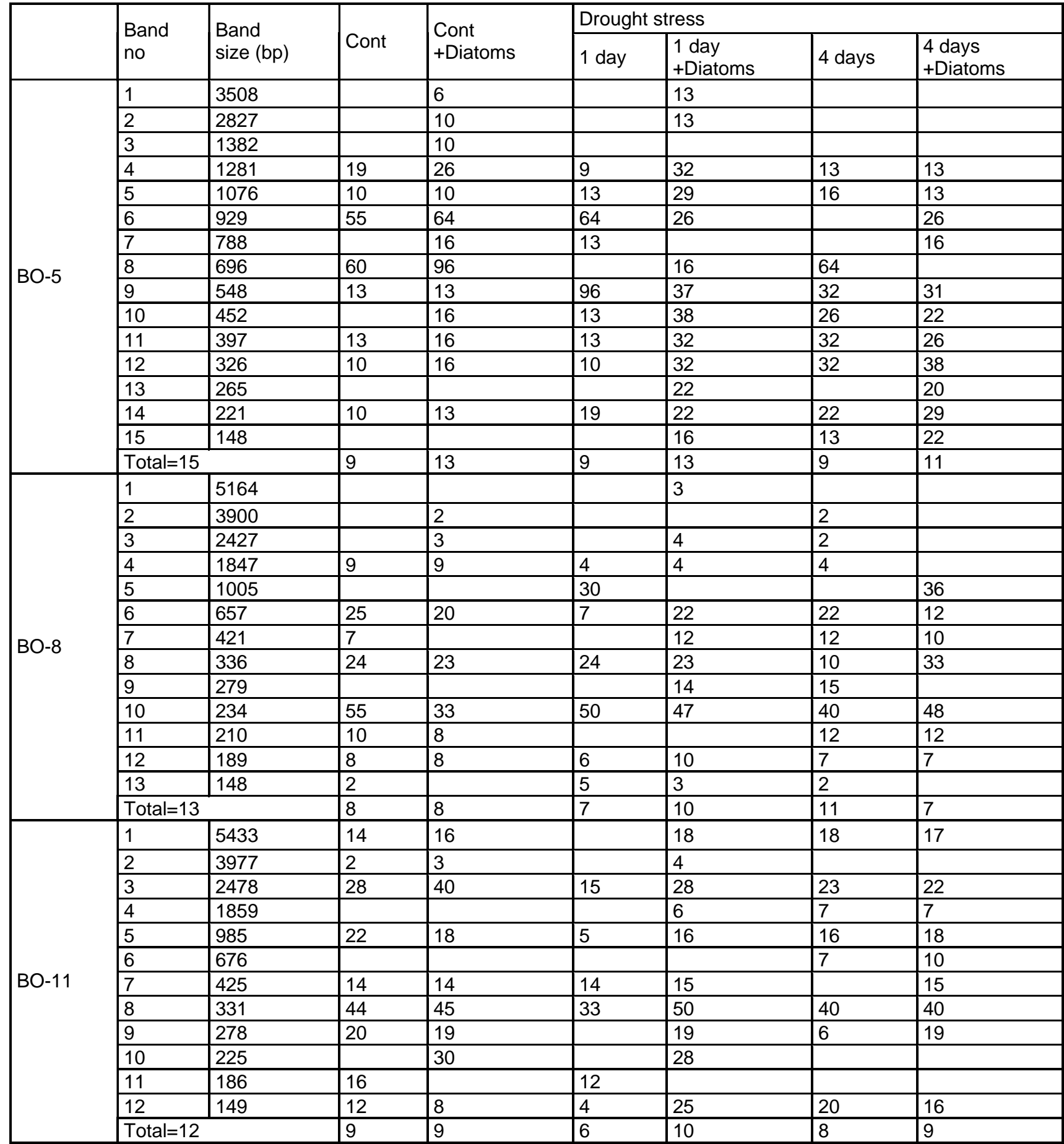

\section{ACKNOWLEDGMENT:}

The author expresses her deepest thanks and gratitude to Dr Raifa A. Hassanein, Professor of Plant
Physiology, Faculty Of Science, Ain Shams University, Dr Abdelfattah Badr, Professor of Genetics, Faculty of Science, Tanta University and Dr. Hanaa Hegazy, Professor of genetics,Faculty of 
Education,Ain Shams University. Thanks are also extended to the Biotechnology Department, National Research Centre, Dokki, Giza for performing the work of protein electrophorasis, RAPD-PCR and HPLC. Sincere thanks and obligations are to my husband and daughters for their encouragement and continuous help throughout this work.

\section{REFERENCES:}

Abdalla, M.M.(2009).Sustainable effects of diatomites on the growth criteria and phytochemical contents of Vicia faba plants. 4th Conference on Recent Technologies in Agriculture, November 2009, Faculty of Agriculture, Cairo University, Giza, Egypt.

Abdalla, M.M. and El-Khoshiban, N.H.(2007). The influence of water stress on growth, relative water content, photosynthetic pigments, some metabolic and hormonal contents of two Triticum aestivum cultivars. Journal of Applied Sciences Research, 3, 12, 2062 2074.

Agarie, S.; Hanaeka, N., Ueno, O., Miyazak, A.; Kubota, F., Agato W. and Kaufman, P.B. (1998). Effects of silicon on tolerance to water deficit and heat stress on rice plants (Oryza sativa L.), monitored by electrolyte leakage. Plant Prod. Sci., 1, 2-96-103.

Arora, A.; Singh, V.P.; Voleti, S.R. and Kushwaha, S.R.(2000). Role of growth regulators in agriculture. Plant Physiol., 3, 191-210.

Bakhat, H.F.; Hanstein, S. and Schubert, S. (2009). Optimal level of silicon for maize (Zea mays L.C.V. AMADEO) growth in nutrient solution under controlled condition. The Proceedings of the International Plant Nutrition Colloquium XVI, Davis.

Balec, R.; Belanger, R.; Chapman, D.M., Epstein,; Guevel, M.H.; Kinrade, S.D., Knight, C.T.G.; Rains, D.W.; Terrill, M. and Wang, J. (2005). Organosilicate chemistry: Evidence for a cross-linking role in plants. Silicon in Agriculture Conference Uberlandia/ MGBrazil.

Banon, S.J.; Ochoa, J.; Franco, J.A.; Alarcon, J.J. and Sanchez-Blanco, M.J. (2006). Hardening of oleander seedlings by deficit irrigation and low air humidity. Environ. And Exp. Bot., 56, 36-43.

Bao-shan, L.; Shao-qi, D.; Li-jun, F.; Shu-chun, Q. and Min, Yu (2004). Effect of TMS (nanostructured silicon dioxide) on growth of Changbai Larch seedlings. Journal of Forestry Research, 15, 2, 138-140.

Bray, E.A. (1997): Plant Responses to water deficit. Trends Plant Sci., 2, 48-54.

Campbell, S.A.; Crone, D.E.; Ceccardi, T.L. and Close, T.J. (1998).A Ca 40KD maize embryo dehydrin is encoded by the dhn2 locus on chromosome 9. Plant Mol. Biol., $38,417-423$.

Carvalho-Pupatto, J.G.; Bull, L.T. and Rodrigues, J.D. (2005). Leaf transpiration and water use efficiency of silicon-treated rice plants. Silicon in Agriculture Conference. Uberlandia/ MG-Brazil.

Chance, B., and Maehly, A.C. (1955). Assay of catalases and peroxidases. Method Enzymol., 2, 764-775.

Crusciol, C.A.C.; Pulz, A.L.; Lemos, L.B.; Soratto, R.P. and Lima, G.P.P. (2009). Effects of silicon and drought stress on tuber yield and leaf biochemical charecteristics in potato. Crop Physiology and Metabolism,49,949-954.

Dakora, F.D. and Nelwamondo, A. (1996). Silicon nutrition promotes root growth and tissue mechanical strength in symbiotic cow pea. Function Plant Biology, 30, 9, 947-953.

Dhindsa, R.S.; Dhindsa, P.P. and Thorpe, T.A. (1980). Leaf senescence correlated with increased levels of membrane permeability and lipid peroxidation and decreased levels of superoxide dismutase and catalase. J. Exp. Bot., 33, 93-101.

Dubois, M.; Cilles, K.A.; Hamilton, J.K.; Rober, P.A. and Smith, F. (1965). Colorimetric method for determination of sugars related substances. Anal. Chem., 28, 350-365.

El-Tayeb, M.A.(2006). Differential response of two Vicia faba cultivars to drought: growth, pigments, lipid peroxidation, organic solutes, catalase and peroxidase activity. Acta Agronomica Hungarica 54, 1, 25-37.

Epstein, E. (1999)."Silicon" Annual Review Plant Physiol. Plant Mol. Biol., 50, 641-664.

Faraz Ahmad, R., Tariq, A.; Mqsood, M.A.; Mukhram, A.T. and Shamsa, K. (2007). Effect of silicon application on wheat (Triticum aestivum L.) growth under water deficiency stress. Emir. J. Food Aqric., 19, 2, 1-7.

Fauteux, F.; Chain, F.; Belzile, F.; Menzies, J.G. and Belanger, R.R. (2006). The protective role of silicon in the Arabidopsis powdery mildew pathosystem. Proc. Natl. Acad. Sci. USA, 103, 17554-17559.

Garwe, D.; Thomson, J.A. and Mundree, S.G. (2002). Molecular characterization of XVSAP1, a stressresponsive gene isolated from the resurrection plant Xerophyta viscosa Baker.Journal of Experimental Botany, 6, 2, 26-37.

Goldberg, H.A. and Warner, K.G. (1997). The staining of acidic proteins on polyacrylamide gels: Enhanced sensitivity and stability of "stain all" staining in combination with silver nitrate. Analyt. Biochem., 251, 227-233.

Gong, H.J.; Chen; K.M.; Zhao, Z.G., Chen, G.C. and Zhou, W.C. (2008). Effects of silicon on defense of wheat 
against oxidative stress under drought at different developmental stages. Biologia Plantarum, 52, 3, 596.

Gong, H.J.; Zhu, X.Y.; Chen, K.M.; Wang, S.M. and Zhang, C.L. (2005): Silicon alleviates oxidative damage of wheat plants in pots under drought. Plant Sci., 169, 313-321.

Graham, G. and Henry, R. (1997). Preparation of fungal genomic DNA for PCR and RAPD analysis in fingerprinting method upon arbitrality primed PCR. In: Michel: M.R. and R.Bova (Eds) Springer Lab. Manual, Vol. 29-34. Springer, Heidel Berg, p 29-34.

Guerrier, G. and Srrullu, D.G. (1990). Development laxes embryonnaire de pois pourvus des reserves. Cand. J. Bot., 68, 742-746.

Hanafy,Ahmad, A.H.; Horb. E.M.; Higazy, M.A. and Morgan, Sh.H. (2008).Effect of silicon and boron foliar applications on wheat plants grown under saline conditions. Science Alert, 10, 1-32.

Hattori, T., Inanaga, H.; Araki, P.An.; Mortia, S.; Luxova, M. and Lux. A. (2005). Application of silicon enhanced drought tolerance in sorghum bicolor. Physiologia Plantarum., 123, 459-466.

Hilbricht, T.; Salamini, F. and Bartels, D. (2002). CpR18, a novel SAP domain plant transcription factor, binds to a promoter region necessary for $A B A$ mediated expression of the CdeT27- 45 gene from the resurrection plant Craterostigma plantagenium Hochst. Plant J. 31, 293-303.

Hou, L.; Eugeniusz, S. and Shangjun, X. (2006). Advances in silicon research of horticultural crops. Vegetable Crops Res. Bullt., 64, 5-17.

Jang, S.W.; Yang, J.C. and Jo, C.J. (2007). Effect of silicon on endogenous plant hormones in tobacco (Nicotiana tabacum L.) Corestra Meet. Agro-Phyto Groups Krakow, Abstr. AP26.

Jessen, L. (2007). Advertising sales business manager. Industry News, 1, 250, 629-677.

Kar, M. and Mishra, D. (1976). Catalase, peroxidase and polyphenol oxidase activities during rice leaf senscence. Plant Physiol. 57, 335-322.

Kawakami, J.; Iwama, K. and Jitsuyama, Y. (2006). Soil water stress and the growth and yield of the potato plants grown from microtubers and conventional seed tubers. Field Crop Research, 95, 89-96.

Kaya, C.; Tuna, L. and Higgs, D. (2006). Effect of silicon on plant growth and mineral nutrition of maize growth under water-stress conditions. Journal of Plant nutrition, 29, 1469-1480.

Kidane, E.G. and Liang, M.D. (2008). Cold stress ameliorating the effect of silicon and its impact on Fasarium wilt of banana. Silicon in Agriculture Conference, South Africa.
Kosobryukhov, A.; Shabnova, N.; Kreslavsky. V. and Matichenkov V. (2008). Active silicon for increasing salt tolerance in plants. Silicon in Agriculturer Conference. South Africa.

Kruger, G. (2006). Certification decision for Diatomite de Mozambique code 1959ZA0600R1educ. South Africa International 1, 3.

Laemmli, U.K. (1970). Cleavage of structural proteins during the assembly of the head of bacteriophage $T_{4}$. Nature, 227, 680-685.

Lalljee, B. (2008). Relationship between available silicon in soils of Mauritius, soil properties and plant silicon concentration. Silicon in Agriculture Conference. South Africa.

Liang,Y,.; Sun, W.; Zhu, Y. and Christie, P. (2007). Mechanisms of silicon- mediated alleviation of abiotic stress in higher plants. A review. Environmental pollution, 147, 422-428.

Lima Filho, O.F.; Tsia, S.M.; Mercante. F.M. and Figueiredo, L.A. (2005). The effect of silicon on nodulation and nitrogen fixation of soybean and bean under Hydroponic conditions III . Silicon in Agriculture Conference. Uberlandia/ MG-Brazil.

Lovisolo, C. and Schuber, A. (1998). Effects of water stress on vessel size xylem hydraulic conductivity in Vitis vinifera L. Journal of Exp. Botany, 49, 321, 693-700.

Lowry, O.H.; Rosenbrough, N.J.; Farr, A.L. and Randall, R.J. (1951). Protein measurement with the folin phenol reagent. J. Biol Chem., 193, 265-275.

Lynch, M.(2008). Silicates in cotemporary Australian farming: A 20- year Review. Silicon in Agriculture Conference. South Africa.

Ma, G.T. and Yamaji, N. (2006). Silicon uptakes and accumulation in higher plants. Review. Trends in Plant Science, 11, 8, 329-397.

Mitani, N,; Chiba, Y.; Yamaji, N. and Ma, J.F. (2008). Silicon transporters in maize and barley-comparison of silicon transporters in different plant species. Silicon in Agriculture Conference. South Africa.

Monti, A.; Amaducci, M.T.; Pritoni, G. and Verturi, G. (2006). Variation in carbon isotope discrimination during growth and at different organs in sugar beet (Beta vulgaris L. ). Field Crops Research, 98, 157-163.

Moons, A.; Bauw, G.; Prinsen, E.; Van Montagu, M. and Van der Streate, D. (1995). Molecular and physiological responses to abscisic acid and salts in roots of salt-sensitive and salt tolerant India rice varieties. Plant. Physiol, 107, 177-186.

Motomura, Y. (1990). Carbohydrate. In Department of Agronomy, Fac. Agric., Tohoku Univ. ed., Guidc. To Experiments in Agricultural Sciences. Soft Science Publications, Tokyo. 206-214. 
Mundree, S.G., Bienyameen, B.; Shaheen, M.; Shaun, P.; Saberi, M.; Clare, V.W.; Kershini, G.; Alice, M.; Samson, M., Jill, H.F. and Jennifer, A.T. (2002). Physiological and molecular insights into drought tolerance. African Journal of Biotechnology . 1,2,28-38.

Nan, R.; Carman, J.G. and Salisbury, F.B. (2002).Water stress, $\mathrm{CO}_{2}$, and photoperiod influence hormone levels in wheat. J. of Plant Physiol. , 159, 307-312.

Nelson, N. (1944). A photometric adaptation of the Somogyi method for the determination of glucose. J. Biol. Chem., 153, 375.

Renault, S., Croser, C.; Fanklin, J.A.; ZwiaZek, J.J. and Mackinnon, M. (2001). Effect of Consoliated tailings water on red-osier dogwood (Conus stolonifera michx) seedlings. Environmental Pollution, 113, 27-33.

Savvas, D.; Giotis, D.; Chatzieustratiou, E.; Bakea, M. and Patakioutas, G. (2009). Silicon supply in soiless cultivations of zucchini alleviates stress induced by salinity and powdery mildew infections. Enviromental and Experimental Botany, 65, 11-17.

Shindy, W.W. and Smith, O.(1975). Identification of plant hormone from cotton ovules. Plant Physiol.; 55, 550558.

Simons., T.S. and Ross, A.F.(1971). Changes in phenol metabolism associated with system resistance to tobacco mosaic virus in Samsun NN tobacco. Phytopath, 61, 1261-1268.
Tahir, M.A.; Rahmatullah, T.; Aziz, M., Ashraf, S.; Kanwal, S. and Maqsood, M.A. (2006). Beneficial effects of silicon in wheat (Triticum aestivum L.) under salinity stress. Pak. J. Bot., 38,5,1715-1722.

Tale Ahmad, S. and Haddad, R. (2008). Study of silicon effects on wheat cultivars under drought stress. Silicon in Agriculture Conference. South Africa.

Wasfy, W.; Shindy, L.R. and Orrin, E.S. (1974). Identification of plant hormones from cotton ovules. Plant Physiology, 55, 550-558.

Williams, J.C.K.; Kubelik, A.R.; Livak, K.J.; Rafalsk., J.A. and Tingey, S.V. (1990). DNA polymorphism by arbitrary primers are useful as genetic markers. Nucleie Acids Res, 18,22,6531-6535.

Yamaji, N.; Mitani, N. and Ma, J.F. (2008). Silicon transporters in rice. Silicon in Agriculture Conference. South Africa.

Zaho, S.J.; Xu, C.C. and Zou, Q. (1994). Improvements of the method for measurement of malondialdehyde in plant tissue. Plant Physiol. Commun., 30, 207-210.

Zhang, M.; Duan, L.; Tian, X.; He, Z.; Li, J.; Wang, B. and $\mathrm{Li}, \quad Z$. (2006). Uniconazole- induced tolerance of soybean to water deficit stress in relation to changes in photosynthesis, hormones and antioxidant system. Journal of Plant Physiology, 6, 1-21. 